ISSN $2081-8130$

DOI: $10.14746 /$ prt.2015.2.4 www.praktykateoretyczna.pl

\title{
WPROWADZENIE DO TŁUMACZENIA FRAGMENTU RĘKOPISÓW EKONOMICZNYCH Z LAT 1861-1863 O POJĘCIACH SUBSUMCJI
}

\author{
BOLÍVAR ECHEVERRÍA
}

Między 1857 a 1865 rokiem Karol Marks sporządził szereg rękopisów, które miały stanowić podstawę jego projektu krytyki ekonomii politycznej. Najważniejszym spośród nich - a ich zawartość została wykorzystana zaledwie częściowo w jedynej księdze Kapitału opublikowanej przez samego Marksa - jest bez watpienia ten sporządzony w latach 1861-1863. Jedna z jego cech dystynktywnych jest to, że pojawiło się w nim, w formie solidnie nakreślonego szkicu, jedno z najważniejszych pojęć krytycznego opisu kapitalistycznego sposobu społecznej reprodukcji, tj. pojęcia subsumcji procesu pracy pod kapitat. Wybrane przez nas fragmenty tego rękopisu, które publikujemy w tym numerze, zawierają niektóre z głównych wskazówek Marksa związanych z tym pojęciem¹. Przedstawiamy je czytelnikom Zeszytón Politycznych (Cuadernos Políticos) nie tylko po to, by pokazać radykalność, którą w przypadku Marksa miało zainicjowanie współczesnego dyskursu krytycznego (i która jest gwarancją jego nieustającej aktualności), ale także dlatego, że być może zmotywują one do właściwszego podejścia wobec problemów teoretycznych, nad którymi debatuje południowoamerykańska lewica.

1 Większość z nich można znaleźć w odpowiednich paragrafach Rezultatón bezpośredniego procesu produkcji, rozdział VI rękopisu z 1865 roku); pochodzą one również z lat 1861-1863: są one niemal dokładną transkrypcją odpowiedniej części rękopisów z tego okresu. W Kapitale Marks stosuje także rozróżnienie na subsumcję realną i formalna; por. np. księgę 1, rozdz. 14, gdzie wykorzystane jest ono do ustanowienia różnicy między wartością dodatkową względną a wartością dodatkową bezwzględną. (W polskich tłumaczeniach pojęcie to znika, występując jako „podporządkowanie” - przyp. red.). 
Narzucają się dwie, prawie niezbadane przez marksistów, możliwości wykorzystania teoretycznego tego pojęcia. Pierwsza sytuuje się w dyskusji wokół istoty nowoczesnej technologii oraz w znaczeniu i możliwościach alternatywnej technologii pokapitalistycznej. Teoria subsumcji ujmuje rzekomo naturalny rozwój nowoczesnej technologii wraz z tym, co byłoby, z jednej strony, jej efektem esencjalnym - „udoskonaleniem” wydajności pracy a z drugiej, efektem akcydentalnym - zniszczeniem zarówno podmiotu wytwórczego, jak i przyrody - jako proces, któremu daleko do spontanicznie postępowej potrzeby wykorzystania osiagnnięć naukowych w produkcji, natomiast który rozwija się raczej z regresymnej konieczności społecznej, czyli z doskonalenia wyzysku siły roboczej. Nowoczesna technologia nie spadła z nieba, aby wywrzeć swoje piętno, dobroczynne czy zgubne, na wytwórczej kooperacji podmiotu społecznego. Wreczprzeciwnie, jest wynikiem narzucenia swoistej formy kooperacji wytwórczej - takiej, która polega na wspólnej praynnależności różnych podmiotów pracujących wyłacznie do kapitału - wobec środków produkcji, ich możliwości technicznych oraz zdolności owego podmiotu społecznego do reakcji przeciwko zatrudniającemu go podmiotom.

Druga, bardziej ewidentna możliwość użycia pojęcia subsumcji, odnosi się do dyskusji w polu metodologii historiografii, szczególnie tych toczonych wokół tzw. formacji społecznoekonomicznych lub „struktury różnych sposobów produkcji”, przede wszystkim w odniesieniu do epoki kapitalistycznej. Teoria subsumcji postrzega sposób istnienia kapitalizmu jako taki, który posiada z konieczności dwie podstawowe wersje lub przybiera dwie postacie nie zawsze następujace po sobie w czasie, ale u₹upetniajace się w danej epoce: formalnq i realnq subsumcje procesu produkcji/konsumpcji społeczeństwa pod proces kapitalistycznej akumulacji. A zatem trzy podstawowe typy, specyficznie kapitalistyczne, spržecznej artykulacji między sposobami produkcji można by znaleźć połączone u podstaw konfliktów społecznych naszych czasów: artykulację formy kapitalistycznej w technicznej rzeczywistości przedkapitalistycznej, artykulację formy kapitalistycznej w rzeczywistości technicznej ustanowionej dla siebie samej i artykulacje nowych, pokapitalistycznych, form społeczeństwa i techniki z totalnością społeczno-techniczną stworzoną przez kapitalizm.

Należy ponadto dodać, że pojęcie subsumcji uzyskuje szczególne znaczenie w odniesieniu do rdzenia specyficznej treści krytycznego dyskursu Marksa - tzn. teorii sprzeczności między społeczno-naturalnym procesem produkcji/konsumpcji a społecznokapitalistycznym procesem pomnażania wartości. To najbardziej zaawansowana z podjętych przez Marksa prób pokazania w ogólnych terminach teoretycznych sposobu, w jaki te dwa sprzeczne procesy są artykułowane. Jeśli już w Zarysie ekonomii politycznej z 1857 roku postrzegał on proces pracy „ucieleśniony” jako „materia” w kapitalistycznej „formie”, w rękopisach 18611863 będzie starał się go dostrzec nie jako rzeczywistość sama w sobie nietknięta przez (kapitalistyczny) zewnętrzny względem niej sposób funkcjonowania, lecz jako „substancję” dotkniętą dogłębnie przez kapitalistyczna „formę”, która, formalnie lub realnie, pozwala na jej istnienie. 
Bolívar Echeverría (1941 - 2010) - meksykański filozof, tłumacz i marksista. W latach sześćdziesiątych XX wieku student Wolnego Uniwersytetu Berlina i uczestnik protestów studenckich. W późniejszym okresie wykładowca Narodowego Uniwersytetu Autonomicznego Meksyku. Założyciel i redaktor licznych pism takich, jak „Palos de la Crítica” czy „Economía Política". Autor publikacji poświęconych przede wszystkim krytyce ekonomii politycznej, teorii krytycznej i kapitalistycznej nowoczesności w odniesieniu do rzeczywistości Ameryki Lacińskiej: w tym El discurso crítico de Marx (1986), Las ilusiones de la modernida (1995) i Vuelta de siglo (2006).

CYTOWANIE: Echeverría, Bolívar. 2015. „Wprowadzenie do tłumaczenia fragmentu Rekopisón ekonomicznych z lat 1861-1863 o pojęciach subsumcji.“ Tłum. Maciej Szlinder. Praktyka Teoretyczna 2(16): 116-118.

DOI: $10.14746 /$ prt.2015.2.4

AUTHOR: Bolívar Echeverría

TITLE: Introduction to the translation of fragment on subsumption from Marx's Economic Notebooks 1861-1863 